\title{
Effect of Dhikr on Blood Pressure in Pregnant Women with Hypertension
}

\author{
Dian Nirmala Sari'1), Masrifan Djamil2), Agus Suwandono ${ }^{3)}$ \\ 1)Applied Midwifery, Graduate Program, School of Health Polytechnics, \\ Ministry of Health Semarang \\ 2)School of Health Polytechnics, Ministry of Health Semarang \\ 3)Universitas Diponegoro, Semarang, Central Java
}

\section{ABSTRACT}

Background: Hypertension is a $5-10 \%$ of complications in pregnancy and is one of the most common causes of death besides bleeding and infection, and also contributes to the morbidity and mortality of pregnant women. The purpose of this study was to examine effect of dhikr on blood pressure in pregnant women with hypertension.

Subjects and Method: This was an experimental study conducted in Banjarnegara district health center, Central Java, in June 2018. A sample of 30 pregnant women with hypertension was selected for this study randomly. The dependent variable was blood pressure. The independent variable was dhikr. Blood pressure was measured by sphygmomanometer. Mean difference between of systolic and diastolic blood pressure in two groups after intervention was tested by $\mathrm{t}$ test.

Results: After intervention, diastolic blood pressure in the intervention group (Mean= Cite this as:

Sari DN, Djamil M, Suwandono A (2020). Effect of Dhikr on Blood Pressure in Pregnant Women with Hypertension. Indones J Med. 05(01): 87-94. https://doi.org/10.26911/theijmed.2020.05.01.12

cc) (7) (2) Indonesian Journal of Medicine is licensed under a Creative Commons

\section{BACKGROUND}

Hypertension is the most common problem in pregnancy. Hypertension is $5-10 \%$ of complications in pregnancy and is one of the most common causes of death besides bleeding and infection, and also contributes to the morbidity and mortality of pregnant women (Cunningham et al., 2014).

Hypertension is included in global problems that hit the world. According to WHO (World Health Organization) data in 2013 cardiovascular disease accounted for
136.67; $\mathrm{SD}=6.17)$ was lower than in the control group (Mean= 141.33; $\mathrm{SD}=5.16)$, and it was statistically significant $(\mathrm{p}=0.006)$. After intervention, diastolic blood pressure in the intervention group $(\mathrm{Mean}=88.67 ; \mathrm{SD}=3.52)$ was lower than in the control group (Mean=92.00; $\mathrm{SD}=4.41$ ), and it was statistically significant $(\mathrm{p}=0.025)$.

Conclusion: Dhikr decreases blood pressure in pregnant women with hypertension.

Keywords: blood pressure, hypertension, pregnant women

\section{Correspondence:}

Dian Nirmala Sari. Applied Midwifery, Graduate Program, School of Health Polytechnics, Ministry of Health Semarang. Jl. Tirto Agung, Pedalangan, Banyumanik, Kota Semarang 50268, Central Java, Indonesia. Email: nirmalasaridian@yahoo.co.id 
disorders, respiratory problems, HELLP syndrome (hemolysis, elevated liver enzymes, low platelet count), and disorders of the fetus such as stunted growth, prematurity until death in the uterus. Hypertension in pregnancy can also continue to preeclampsia and eclampsia which can cause death in both mother and fetus (Lindheimer et al., 2008; Seely and Ecker, 2014; Brown et al., 2018).

Maternal death according to the WHO definition is death during pregnancy or within a period of 42 days after the end of pregnancy, due to all causes related to or aggravated by pregnancy or treatment, but not caused by an accident/ injury (Ministry of Health, 2014).

Government programs have been carried out to overcome the problem of maternal mortality in Indonesia, but have not overcome the problem because the Maternal Mortality Rate (MMR) is still high. Based on the 2012 Indonesian Demographic and Health Survey (IDHS), the maternal mortality rate in Indonesia is still high at 359 per 100,00o live births. This figure is slightly decreased when compared to the 1991 IDHS, which is 390 per 100,000 live births. This number has declined slightly even though it is not too significant. The fifth global target of MDGs (Millennium Development goals) is to reduce MMR to 102 per 100 ,000 live births in 2015. Referring to current conditions, the potential to achieve the fifth MDG target to reduce MMR is off track, meaning that hard work is needed. really to achieve it (Ministry of Health, 2014).

The Central Java Province maternal mortality rate in 2012 was based on reports from the district/ city of 116.34/ 100,000 live births, an increase compared to the MMR in 2011 of 116.01/ 100,000 live births. The highest cases of hypertension occur in the entire region of Central Java with a total of 554,771 cases $(67.57 \%)$ in 2012. This case also includes hypertension in pregnancy (preeclampsia). The number of complications in pregnancy is 126,806 (Provincial Health Office of Central Java, 2013).

Maternal mortality rate in Banjarnegara district in 2016 was 120.3 of live births, which in absolute terms were calculated from the number of maternal deaths by 19 with live births of 15,798 babies. This figure increased compared to 2015, which was $107.61 / 100,000$ live births. The main cause of maternal death is hypertension in pregnancy $31.6 \%$ (Banjarnegara district health office, 2016).

Handling cases of hypertension in pregnant women has been carried out by giving pharmacological therapy and nonpharmacology (Ministry of Health, 2013). For pharmacological therapy that is by giving metildhopa and nifedipine. According to WHO (2017) giving pharmacological therapy has side effects namely dizziness, hypotension, fatigue, depression, hypoglycemia, IUGR. Therefore, efforts are needed in addition to giving these therapies, namely by giving non-pharmacological therapy namely dhikr.

Dhikr is a relaxation technique that is by incorporating elements of belief (Benson and Proctor, 2000). The effect of relaxation will produce an alpha wave frequency in the brain that can cause feelings of happiness, pleasure, joy and confidence so that it can suppress the release of cortisol, epinephrine and noreepinephrine hormones which are strong vasoconstriction in blood vessels. Emphasis on these hormones can lead to dilatation of blood vessels so that blood pressure drops (Beevers et al., 2001; Delacroix et al., 2014).

Nasriyati et al. (2016), stated that with dhikr meditation done twice at 6-8 hours and 12-14 hours postoperatively for 25 
minutes produced systolic and diastolic blood pressure in the treatment group experienced a significant decrease. However, there were no differences in blood pressure, pulse and respiration between the treatment and control groups.

Previous study examine the effect of dhikr 3 times/ week for 3 weeks with a 25minute duration on blood pressure (Mirzaei et al., 2015; Nasiri et al., 2017; Pahlevi et al., 2017). The purpose of this study was to examine effect of dhikr on blood pressure in pregnant women with hypertension.

\section{SUBJECTS AND METHOD}

\section{Study Design}

This was an experimental study carried out at Pagedongan and Mandiraja health centers, Banjarnegara, Central Java, from May to June 2018.

\section{Population dan Sample}

The target population was all pregnant women with hypertension. A sample of 30 pregnant women with hypertension was selected randomly.

\section{Study Variables}

The dependent variable was blood pressure. The independent variable was dhikr.

\section{Operational Definition of Variables} The provision of dhikr intervention in the treatment group: the pregnant women was relaxed, eyes closed, inhaled deeply, and then said sholawat the prophet 1 time, "ya lathif", "ya mubdi'u ya khalik", "ya rahman ya rahim", "ya sami 'yes bashir", "ya ghaffar", "ya sallam" each once, subhanallah 33x, allohuakbar 33x, la ilaha illalah 33x, astagfirulloh 33x alhamdulillah 33x for 25 minutes done 9 times a week 3 times. Data collected through observation sheets.
The measurement scale was categorical. The instrument was a dhikr module.

Blood pressure was a systolic and diastolic blood pressure which measured using sphygmomanometer. Measurements were made before the dhikr intervention and 25 minutes after the intervention. The measurement scale was continous.

\section{Data Analysis}

Univariate analysis was carried out to describe the frequency distribution and characteristics of pregnant women. Sample characteristics of continous data were described in mean, SD, minimum, and maximum. Sample characteristics of categorical data were described in $\mathrm{n}$ and \%. Mean difference of systolic and diastolic blood pressure between in two groups after intervention was tested by t test

\section{Research Ethic}

Research ethics included informed consent, respect, confidentiality, and ethical clearance. Ethical clearance was carried out at the health polytechnic of the Health Ministry of Semarang and was declared ethically feasible based on the number of the decision letter number 438/KEPK/poltekkesSmg/EC/2018.

\section{RESULTS}

\section{Sample Characteristics}

Distribution of the sample characteristics of continous data were described in Table 1. Distribution of the sample characteristics of categorical data were described in Table 2. Figure 1 shows that mean of systolic blood pressure in the intervention group was lower than in the control group. Figure 2 above shows that mean of diastolic blood pressure in the intervention group was lower than the control group.

Table 1. Sample characteristics of continous data

\begin{tabular}{lcccc}
\hline Sample Characteristics & Mean & SD & Min. & Max. \\
\hline Age (years old) & 32.60 & 6.2 & 18 & 45 \\
\hline
\end{tabular}


Sari et al./ Effect of dhikr on blood pressure

Table 2. Sample characteristics of categorical data

\begin{tabular}{lcc}
\hline Sample Characteristics & n & \% \\
\hline Parity & \multicolumn{2}{c}{} \\
$\quad$ Primiparous & 6 & 20 \\
Multiparous & 23 & 76.7 \\
$\quad$ Grandemultiparous & 1 & 3.3 \\
Occupation & & \\
$\quad$ Employed & 10 & 33.3 \\
$\quad$ Unemployed & 20 & 67.7 \\
Education & & 6.7 \\
$\quad$ Senior high school & 2 & 16.7 \\
$\quad$ Junior high school & 5 & 76.7 \\
\hline Elementary school & 23 & \\
\hline
\end{tabular}

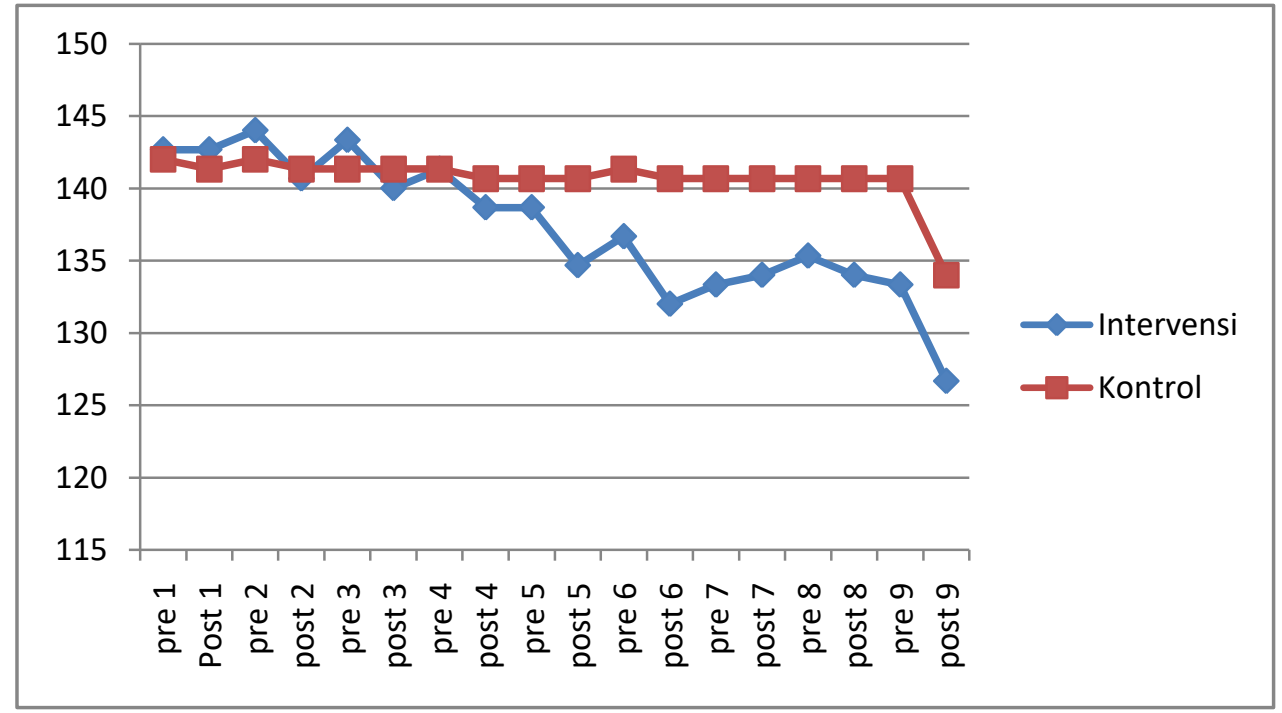

Figure 1. Change in mean systolic blood pressure in the intervention and control groups

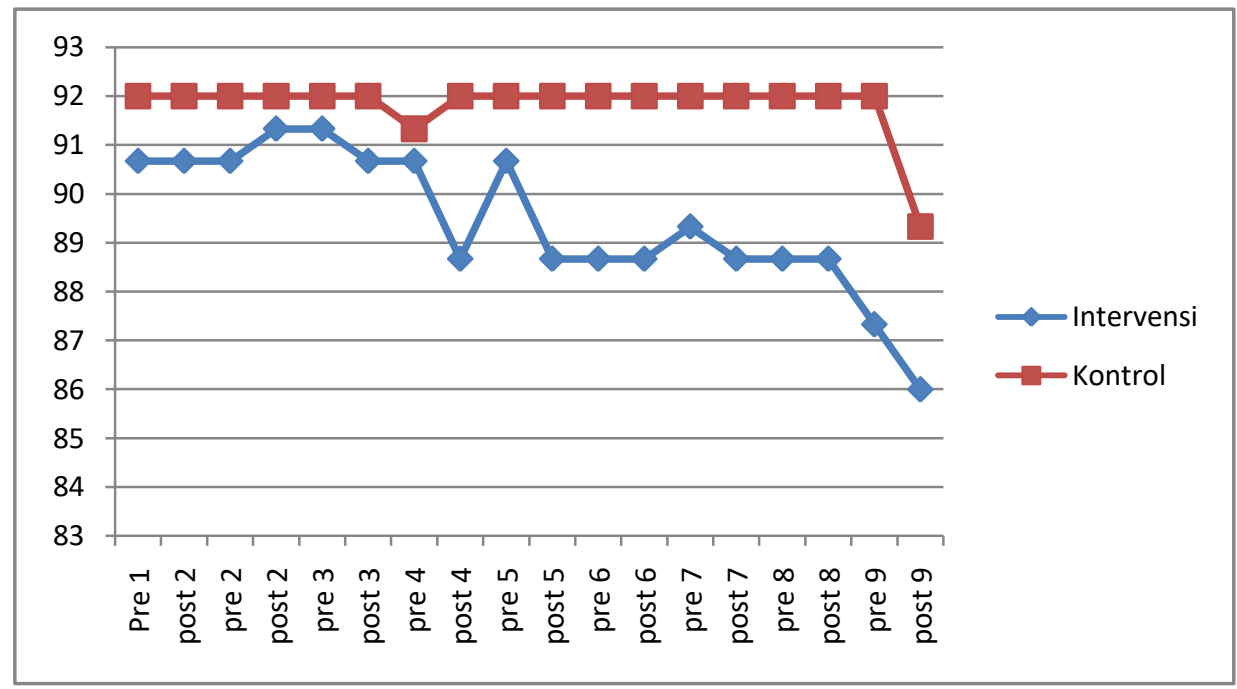

Figure 2. Mean of diastolic blood pressure in the control and intervention groups 
Sari et al./ Effect of dhikr on blood pressure

2. Bivariate Analysis

Table 3. Difference of systolic blood pressure in control and intervention groups before intervention

\begin{tabular}{lccc}
\hline Group & Mean & SD & p \\
\hline Control & 140.67 & 5.94 & 0.271 \\
Intervention & 138.67 & 3.52 & \\
\hline
\end{tabular}

Table 4. Difference of systolic blood pressure in control and intervention groups after intervention

\begin{tabular}{lccc}
\hline Group & Mean & SD & p \\
\hline Control & 141.33 & 5.16 & 0.006 \\
Intervention & 136.67 & 6.17 & 0.6 \\
\hline
\end{tabular}

After intervention, diastolic blood pressure in the intervention group (Mean= 136.67; $\mathrm{SD}=6.17$ ) was lower than in the

Table 5. Difference of diastolic blood pressure in control and intervention groups before intervention

\begin{tabular}{lccc}
\hline Group & Mean & SD & p \\
\hline Control & 91.33 & 5.16 & 0.638 \\
Intervention & 90.67 & 2.58 & \\
\hline
\end{tabular}

Table 6. Difference of diastolic blood pressure in control and intervention groups after intervention

\begin{tabular}{lccc}
\hline Group & Mean & SD & p \\
\hline Control & 92.00 & 4.41 & 0.025 \\
Intervention & 88.67 & 3.52 & \\
\hline
\end{tabular}

After intervention, diastolic blood pressure in the intervention group (Mean= 88.67; $\mathrm{SD}=3.52$ ) was lower than in the control group (Mean= 92.00; $\mathrm{SD}=4.41)$, and it was statistically significant $(\mathrm{p}=$ 0.025).

\section{DISCUSSION}

In pregnancy hypertension due to a decrease in blood flow and uterine perfusion that stimulates excessive renin release, causing renin to be released will flow with the blood to the liver and react with angiotensinogen to convert angiotensin I to angiotensin II which when accumulated with thromboxane will cause vasoplasm which causes the anteriol lumen to narrow and the anteriol pressure increase. In control group (Mean= 141.33; $\mathrm{SD}=5.16)$, and it was statistically significant $(\mathrm{p}=$ 0.006). 
the body resulting in a decrease in blood pressure, pulse and breathing (Mirzaei et al., 2015; Nasiri et al., 2017; Pahlevi et al., 2017).

Dhikr is a relaxation technique that is by incorporating elements of belief (Benson and Proctor, 2000). The element of dhikr that is related and has a relationship with the relaxation technique of attitude that is surrender. Resignation is a form of passivity that is needed in relaxation (Tangsangwornthamma, 2018). This can produce an alpha wave frequency in the brain that can cause feelings of happiness, pleasure, joy, and confidence so that it can suppress the release of cortisol, epinephrine and norepinephrine hormones which are strong vasoconstriction in blood vessels. Emphasis on these hormones can lead to dilatation of blood vessels which results in decreased vascular resistance so the end result is a decrease in blood pressure (Beevers et al., 2001; Delacroix et al., 2014).

Haryono (2017) in his study on the combination of back massage and dzikir on blood pressure in patients with essential hypertension, the intervention carried out for 3 consecutive days can reduce significant systolic blood pressure with $\mathrm{p}=0.040$.

One of the systolic blood pressure is influenced by psychological factors so that relaxation will get calm and systolic pressure will drop, besides that systolic blood pressure is also affected by systemic circulation and pulmonary circulation so that with relaxation meditation which focuses on breathing regulation there will be a decrease in pulse and decrease in blood pressure sistole. While diastole pressure is associated with coronary circulation, if the coronary arteries undergo atherosclerosis will affect the increase in diastolic blood pressure (Anderson et al., 2008; Goldstein et al., 2012; Brook et al., 2013; Lu et al., 2017; Levine et al., 2017).

\section{AUTHOR CONTRIBUTION}

Dian Nirmala Sari run the experiment study, examined the blood pressure, and wrote the manuscript. Masrifan Djamil and Agus Suwandono did data analysis and interpreted the results.

\section{FUNDING AND SPONSORSHIP}

There was no external funding.

\section{CONFLICT OF INTEREST}

None.

\section{ACKNOWLEDGEMENT}

We thank to Banjarnegara district health center which permit to collect the data and run the study.

\section{REFERENCE}

Anderson JW, Liu C, Kryscio RJ (2008). Blood pressure response to transcendental meditation: A meta-analysis. Am J Hypertension. 21(3): 310-316. https://doi.org/10.1038/ajh.2007.65

Banjarnegara District Health Office (2016). Profil Kesehatan (Banjarnegara health profile).

Beevers G, Lip GYH, O'Brien E (2001). The pathophysiology of hypertension. BMJ. 322(7291): 912-916. https://dx.doi.org/10.1136\%2Fbmj.322.7291.91 2.

Benson H, Nilandari A, Nurhasan, Proctor W (2000). Dasar-dasar respons relaksasi: bagaimana menggabungkan respons relaksasi dengan keyakinan pribadi anda. Bandung: Kaifa.

Brook RD, Appel LJ, Rubenfire M, Ogedegbe G, Bisognano JD, Elliott WJ, Fuchs FD, Hughes JW, et al. (2013). Beyond medications and diet: Alternative Approaches to lowering blood pressure. A scientific statement from the American Heart Association. Hypertension. 61: 1360-1383. Doi: 10.1161/HY- 
Sari et al./ Effect of dhikr on blood pressure

P.obo13e318293645f

Brown MA, Magee LA, Kenny LC, Karumanchi SA, McCarthy FP, Saito S, Hall DR, et al. (2018). Hypertensive disorders of pregnancy: ISSHP classification, diagnosis, and management recommendations for international practice. Hypertension. 72: 24-43. Doi: 10.1161/HYPERTENSIONAHA.117.10803.

Cunningham FG, Leveno KJ, Bloom SL, Dashe JS, Hoffman BL, Casey BM, Spong CY (2014). Williams Obstetrics 25th ed. Texas: Mcgraw-hill.

Delacroix S, Chokka RG, Worthley SG (2014). Hypertension: Pathophysiology and Treatment. J Neurol Neurophysiol, 5: 6. Doi: 10.4172/2155-9562.1000250 .

Goldstein CM, Josephson R, Susan Xie S, Hughes JW (2012). Current perspectives on the use of meditation to reduce blood pressure. https://doi.org/10.1155/2012/578397

Haryono R, Permana I, Chayati N (2017). Pengaruh kombinasi pijat punggung dan dzikir terhadap tingkat stres pada penderita hipertensi. Jurnal Keperawatan Notokusmo, 5(1): 1-6.

Levine GN, Lange RA, Bairey-Merz CN, Davidson RJ, Jamerson K, Mehta PK, Michos ED, et al. (2017). Meditation and cardiovascular risk reduction. $\mathrm{J}$ Am Heart Assoc. 6(10): e002218. https://doi.org/10.1161/JAHA.117.00 2218

Ministry of Health (2013). Buku saku pelayanan kesehatan ibu di fasilitas kesehatan dasar dan rujukan. Jakarta: Indonesian Ministry of Health.

Ministry of Health (2014). Mother's day situasi kesehatan ibu. Infodatin. Jakarta: Indonesian Ministry of Health.

Kowalak JP, Welsh W, Mayer B (2011) Buku ajar patofisiolog. Jakarta: EGC.
Lindheimer MD, Taler SJ, Cunningham FG (2008). Hypertension in pregnancy. J Am Soc Hypertension. 2(6): 484-494. https://doi.org/10.1016/j.jash.2008.1 0.001

Lu S, Donglan Z, Liang W, Junyang Z, Rebecca C, Liwei C (2017). Meditation and blood pressure a meta-analysis of randomized clinical trials. J Hypertension, 35(4): 696-706. doi: 10.1097/HJH.oooooooooooo1217

Mirzaei T, Nematollahi M, Sabzevari S, Dehghan S, Soleymanpour MJ (2015). Short term effects of islamic zikr on anxiety, stress, and depression in mothers of children with congenital heart disease. British J Med \& Medical Research. 10(4): 1-5. https://doi.org/10.9734/BJMMR/2015/19526

Nasiri M, Naboureh A, Fayazi S (2017). The effect of an islamic praise (Zikr) on postoperative anxiety of patients undergoing coronary artery by passes graft surgery: A randomized clinical trial on Iranian Shia Muslims. Research in Cardiovascular Medicine, 6(3): 4. Doi: 10.5812/cardiovascmed.41388

Pahlevi R, Putra ST, Sriyono (2017). Psychoneuroimmunology approach to improve recovery motivation, decrease cortisol and blood glucose of DM type 2 patients with dhikr therapy. Jurnal Ners. 12(1). http://dx.doi.org/10.20473/jn.v12i1.2315

Provincial Health Office of Central Java (2013). Profil kesehatan provinsi jawa tengah tahun 2012. Semarang: Dinkes Jateng.

Seely EW, Ecker J (2014). Chronic Hypertension in Pregnancy. Circulation. 129(11): 1254-1261. https://doi.org/10.1016/j.ajog.2019.11.1243

Tangsangwornthamma T (2018). A qualitative study on belief, perception, and 
Sari et al./ Effect of dhikr on blood pressure

health effects on standing zikr among Thai muslims in Nakhon Nayok Province. Psychology Research. 8(11): 544-557. doi:10.17265/2159-5542/2018.11.002

WHO (2013). A global brief on hypertension. https://www.who.int/cardiovas-

cular_diseases/publications/global_b rief_hypertension/en/

WHO (2017). Pocket book of hospital care for mothers. World Health Organization. Regional Office for South-East Asia. https://apps.who.int/iris/handle/10665/258716. 